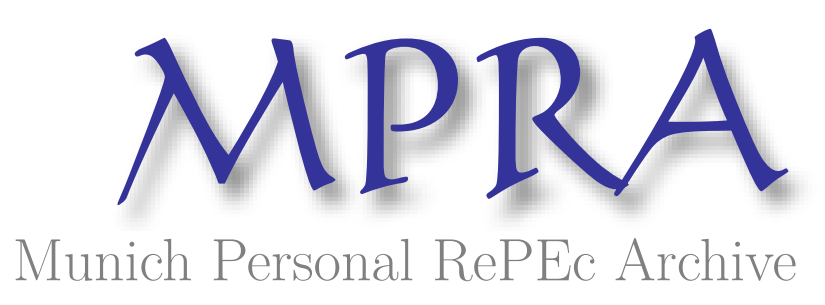

\title{
Average Cost and Marginal Cost Pricing in Marshall: Textual Analysis and Interpretation
}

zamparelli, luca

New School University

September 2007

Online at https://mpra.ub.uni-muenchen.de/6053/

MPRA Paper No. 6053, posted 03 Dec 2007 03:27 UTC 


\title{
Average Cost and Marginal Cost Pricing in Marshall: Textual Analysis and Interpretation*
}

\author{
Luca Zamparelli ${ }^{\dagger}$
}

September 11, 2007

\begin{abstract}
This paper proposes a textual analysis of Marshall's theory of firm pricing behavior under competitive conditions. It considers to what extent average cost and marginal cost pricing rules characterize Marshall's competitive partial equilibrium, and it shows that the two rules differ for origins and can be reconciled only with great difficulty in a general equilibrium framework.

Keywords: Marshall, classical competition, perfect competition, marginal and average cost

JEL Classification: B12, B13, D41, D46

'Only through the principle of competition has political economy any pretension to the character of science' (Mill, 1848, II: 239)
\end{abstract}

\section{Introduction}

Partial long-run competitive equilibrium requires the equality of price, marginal and average cost of production. This condition assures the equilibrium both of the individual firm and of the industry. The former is maximizing its profit by producing a quantity where marginal cost equals marginal revenue, and, at the same time, there are no incentives to enter or exit the latter as it yields the normal rate of profit. In what follows I argue that average cost and marginal cost pricing theories have very distinct origins as they are rooted, respectively, in the classical and marginalistic theory of competition. I will analyze to what extent

\footnotetext{
*This paper draws material from my laurea dissertation defended at University of Roma Tre. The supervision and guidance of P. Garegnani are thankfully acknowledged. I am grateful to A. Palumbo for her criticism and encouragement during the elaboration of the dissertation. I should like to thank D. Foley, G. Mongiovi, F. Ravagnani, F. Vianello, partecipants at a seminar held at 'Centro Studi Piero Sraffa' in 2005, and two anonymous referees for their helpful comments and suggestions. The usual disclaimers apply.

${ }^{\dagger}$ Department of Economics, New School for Social Research. E-mail: zamp1472@newschool.edu. Address for correspondence: 106 Manhattan avenue apt.3, 11206, Brooklyn, NY, U.S.
} 
and under which circumstances they joined in the work of Alfred Marshall and his followers and I will argue they are incompatible in a general equilibrium framework unless constant returns to scale are assumed. The analysis of Marshall's work and its relation to the classical school on one side and to Cournot on the other, shows that only partial evidence can be found to support the adoption of the notion of marginal cost pricing by Marshall. However, it will be argued, he developed some concepts, such as the distinction between short and long periods and the notion of quasi-rents, which turned out to be fundamental for the joint acceptance of marginal cost and average cost pricing principles by the Marshallian school.

The rest of the paper is organized as follows. Section 2 reviews the main features of classical and perfect competition through the work of Adam Smith and Cournot; Section 3 describes the relationship between Marshall and the classical tradition; Section 4 is dedicated to Cournot's influence on Marshall; Section 5 analyzes Marshall's theory of competition and supply; Section 6 links Marshall's work and the recent debate on value theory and Section 7 concludes with some remarks.

\section{Classical and marginalistic competition}

The discontinuity between the classical notion of competition and the neoclassical perfect competition has been widely emphasized in economic literature; it has been stressed by Hayek (1948) and later endorsed and further elaborated by others (see for example Stigler, 1957; McNulty, 1967, 1968, 1987; Harris, 1988, Backhouse, 1990; Blaug, 1997). The basic idea is that in classical political economy competition keeps its everyday-life meaning. It is the process ${ }^{1}$ the race by which producers and buyers compete either for market shares or the availability of goods; the outcome of this process is the tendency of prices and rate of rewards of productive resources to their natural levels. The neoclassical notion (whose first analytical formulation is due to Cournot, 1838), on the contrary, would describe the final state of the economy, where the competitive process comes to rest. It is a market condition defined in terms of number of agents and their capability of affecting prices; such capacity is null under perfect competition. Hence the paradox that perfect competition rules out any actual competitive activities:

'. . the modern theory of competitive equilibrium assumes the situation to exist which a true explanation ought to account for as the effect of competitive process...' (Hayek, 1948, 94)

'Competition came to mean, with the mathematical economists, a hypothetically realized situation in which business rivalry, or competition in the Smithian sense, was ruled out by definition.' (McNulty, 1967, 398)

\footnotetext{
${ }^{1}$ See for example Blaug $(1997,67)$ : 'for Smith competition is not a state or a situation but a behavioural activity..' and Harris $(1988,140)$ : 'The classical conception of competition is that it is a process, not a state.'
} 
'... perfect competition deals with a situation where competition, as the term is commonly understood, is absent.' (Backhouse, 1990, 58)

According to McNulty, this absence of actual competitive behavior under perfect competition would render the two notions of competition not only different but also incompatible: 'For Smith, then, competition was a process through which a predict result, the equation of price and cost, was achieved. With Cournot it became the realized result itself. The two concepts are not only different; they are fundamentally incompatible.' (McNulty, ibid.) The last statement is not uncontroversial; we aim at analyzing to what extent the two concepts of competition merged in the Marshallian theory of the firm, and what is the historical process that led to such coexistence.

\subsection{Smith's gravitation}

As we said, competition in classical political economy enforces the tendency of prices towards their costs of production. We can illustrate this mechanism by referring to Smith's description of the gravitation process (Smith, 1776, I, vii). Smith introduces the concept of effectual demand as the quantity of goods, which the market would absorb at its cost of production (or natural price). If the quantity brought to market is lower than effectual demand, then competition between buyers brings the market price of the commodity above its normal price. As this causes the rate of profit to rise above the normal level there will be an incentive for new capital to enter that trade, production will increase, market prices will be forced down and normal profitability will be restored. A symmetric mechanism assures the tendency of market prices to their natural values if the quantity brought to market is initially higher than effectual demand. The outcome of this process is therefore that 'natural price is, as it were, the central price, to which the prices of all commodities are continually gravitating' (ibid., 75). Free mobility of resources among different productions is required to make this process operate effectively.

\subsection{Cournot and perfect competition}

Cournot (1838, Ch. IV) adopted a downward sloping demand curve to describe the market of a commodity. Without any kind of microfounded rationale, he stated the existence of a continuous (and differentiable) function, which, for any given price, indicates the amount of the good the market would absorb. ${ }^{2}$ In the analysis of monopoly (Ch. V), he introduced the profit maximizing behavior of the firm and he derived the optimality condition as the point where the marginal revenue of an additional unit of output equals its marginal cost of production. Competition is introduced by adding producers in the market. The way they interact in the market has become so famous to be named after the French mathematician: firms adopt a Cournot-competition behavior if they take total supply as given and they maximize their revenue on the residual portion

\footnotetext{
${ }^{2}$ Dupuit (1844) was the first economist to establish explicitly the connection between demand and marginal utility.
} 
of the demand function. Cournot proved the existence of a stable equilibrium where all firms (if they share the same technology) produce the same amount of good; equilibrium price is a monotonic decreasing function of the number of participants in the market. In the limit, when the number of firm tends to infinity and the quantity produced by each of them becomes inappreciable, price equals marginal cost.

He saw clearly that this equality allowed him to express the production of any firm as a mere function of price and, in turn, to derive the supply function of the market as the horizontal sum of individual supplies. More, he stressed that marginal cost functions must be increasing 'otherwise the gross value of the product [..] would be less than the costs of production..' (ibid., VIII, 91); in case marginal costs are decreasing it means 'that the effect of monopoly is not wholly extinct, or that the variation of the amount produced by each individual producer affects the total production of the article, and its price, to a perceptible extent' (ibid., 91-92): competition and increasing returns are incompatible.

Cournot carefully ruled out the possibility of competitive firms producing with decreasing costs, as the marginal cost pricing would let them have losses. On the other hand he was not troubled by the possibility that the equilibrium may occur at a point where, although 'the effects of competition have reached their limit', firms are earning profits, which is the case with increasing marginal costs. Contrary to the classical tradition where competition erases profits, perfect competition, at its very birth, did not require the absence of profits. Cournot's analysis lacks a temporal dimension: elaborating the distinction between short and long period will be a fundamental step in reconciling marginal cost pricing with the zero-profit equilibrium condition. ${ }^{3}$

\section{Continuity and discontinuity between Marshall and the classical tradition}

The most eminent biographers and editors of Marshall's work (see for example Groenewegen 1995, Guillebaud 1960 in Marshall 1920, Keynes 1924, and Whitaker in Marshall 1975) have emphasized the influence of the classical tradition on Marshall's economic apprenticeship. Marshall himself stressed the continuity between his work and the classical political economy. ${ }^{4}$ He approached political economy in 1866-67 by reading Mill's (1848) Principles of Political

\footnotetext{
${ }^{3}$ As early as in 1844 Dupuit formulated the distinction between short and long term equilibrium. He anticipated Marshall's analysis on so many fundamental points that the suggestion to talk of 'Dupuit-Marshall theory of competitive equilibrium' by Ekelund and Hèbert (1999) should be welcome. In our reconstruction, we do not analyze Dupuit's contribution in detail, as Marshall did not have direct knowledge of his work until he had fully developed his own analysis. ('..it seems quite likely that Dupuit's work was completely unknown in England until Jevons came upon it in the later 1870s.', Whitaker in Marshall, 1975, II: 281')

${ }^{4}$ Marshall's claims of continuity with the classical tradition should be warily considered as 'he had a pronounced tendency so to phrase his own doctrines as to minimize the change from the classical tradition.' (Stigler, 1941, 63)
} 
Economy, which he considered as the basis for his 'translation' into mathematics of Ricardo's theory:

'While still giving private lessons in mathematics, he translated as many as possible of Ricardo's reasonings into mathematics; and he endeavoured to make them more general' (Marshall, Autobiography, in Keynes, 1924, 328)

'... my main position as to the theory of value and distribution was practically completed in the year 1867-70, when I translated Mill's version of Ricardo's or Smith's doctrines into mathematics' (Marshall, letter to Clark, 24/iii/1908, in Pigou 1925, 416).

As we discussed above, the value of a good in Smith's analysis is determined by its cost of production; the relation between demand and supply of a good does not enter the determination of the natural price but only market prices' deviations from it. Obviously, Smith and the classical economists clearly acknowledged the role of patterns of demand in determining the composition and the scale of output; accordingly, they understood that, under non-constant returns to scale, demand affects normal prices. However, as the idea of the simultaneous determination of prices and quantities was extraneous to the classical economists they could focus on technology and distribution when studying the determinants of value. ${ }^{5}$

Mill (1848) began to introduce changes in this notion of value. He suggested that goods could be divided into three categories according to the laws that regulate their value. Goods available in given amount constitute the first class. In this case, the equality between demand and supply regulate their value: supply is given and equality is achieved by changes in demand. The point to be stressed is that demand is characterized as a function of price and Mill is aware of the important break with respect to the classical tradition he is introducing: '... it is usually supposed (...) that the value depends upon the ratio between effectual demand, as thus defined [Mill is here referring to Smith], and the supply'. (Mill, 1848, III, ii, §3, 465) On the contrary, the value of a good is not the outcome of a ratio between two given quantities, demand changes as a function of price, which settles at the level where demand equals supply: '.. the quantity demanded is not a fixed quantity, even at the same time and place; it varies according to the value (...) The idea of a ratio as between demand and supply is out of place $(\ldots)$ the proper mathematical analogy is of an equation' (ibid., 465-7)

Goods indefinitely reproducible belong to the second class. For this class the law of the cost of production as the sum of normal wages and profit holds

\footnotetext{
${ }^{5}$ From a neoclassical point of view, neglecting demand in the theory of value can be understood only by assuming constant returns. This is exactly Marshall's interpretation of the classics. According to him, Ricardo, although aware of the laws of decreasing and increasing returns, decided to assume constant returns when deriving his theory of value. In turn, he prevented demand to play any role in the determination of normal value. (see Marshall, 1920, I: 814) Early Sraffa arrived to analogous conclusions: 'In normal cases the cost of production of commodities produced competitively -... - must be regarded as constant in respect of small variations in the quantity produced' (Sraffa, 1926, 540-1). Only later Sraffa (1960) suggested separating the analysis of prices and quantities so that the issue of returns to scale is irrelevant to determine the influence of demand on prices (Sraffa, 1960, Preface).
} 
without substantial changes with respect to the classical tradition. In this category, demand and supply maintain a role in determining the market values if different from the natural ones: 'The real law of demand and supply, the equation between them, still holds good: if a value different from the natural value be necessary to make the demand equal to supply, the market value will deviate from the natural value.' (ibid., 475)

The third class finally, encompasses goods whose reproduction may be indefinite but implies increasing costs: 'commodities which can be multiplied to an indefinite extent by labour and expenditure, but not by a fixed amount of labour and expenditure..'. (ibid., 464)

To sum up: '... demand and supply govern the value of all things which cannot be indefinitely increased (...). But in all things which admit of indefinite multiplication, demand and supply only determine the perturbations of value, (...). While still ruling the oscillations of value, they themself obey a superior force, which makes value gravitate towards Cost of Production (...) demand and supply always rush to an equilibrium, but the condition of stable equilibrium is when things exchange for each other according to their cost of production, or, in the expression we have used, when things are at their Natural Value.' (ibid., 476) Cost of production and demand and supply coexist as complementary explanations of value for different classes of goods. However, the occurrence of a change with respect to the classical theory of value is apparent. Dardi $(1984,54)$ underlines the identification of the 'stable equilibrium' and the classical 'Natural Value'. It would seem that natural price became the equilibrium price in the constant returns to scale case, thus assuming just a particular and subordinate role in determining the value of a good with respect to the action of demand and supply. Marshall would take the next step: by claiming the generality of the non-constant returns to scale production he will be able to guarantee demand a central role in value theory.

Before moving to Marshall however, it is worth commenting briefly on a controversy between Mill and Thornton, which contributed to move value theory further in the direction of the supply and demand approach. In On Labour Thornton (1869) tries to show the non-existence of the theory of value in general: '....inasmuch as the sole function of scientific law is to predict the invariable recurrence of the same effects from the same causes, (...) price cannot possibly be subjected to law', (Thornton, 1869, II, i, 82) and, in particular of the supply and demand approach: 'The question we are discussing is wheter it be true that price is determined by supply and demand; (...) [and] that the prices at which sales take place are those at which supply and demand are equalised' (ibid., 54).

According to Thornton, since prices are the outcome of the bargaining process between buyers and sellers they lie within buyers' and sellers' reservation prices. Sellers, who will try to obtain the highest possible price at which they can sell their whole stock of goods, usually set prices. In their search of the highest price, they will moderate their demands for the fear of other sellers' competition: such competition determines prices. Unfortunately, since competition does not follow any rule, the same has to be said for price determination: '... there [is] no law of competition. Neither $(\ldots)$ if competition be $(\ldots)$ the 
determining cause of price, can there be any law of price.' (ibid., 80-1)

In order to prove wrong the demand and supply approach Thornton provides a series of practical examples where prices at which transactions occur do not equate demand and supply. In his reply, Mill concedes the possibility of such cases, which however have to be seen as anomalies not invalidating the general law of value:

'Instead of conflicting with the law, this is the extreme case which proves the law. The law is that the price will be that which equalises the demand with the supply; and the example proves that this only fails to be the case when there is no price that would fulfil the condition, and even then, the same causes, still operating, keep the price at the point which will mostly nearly fulfil it.' (Mill, $1869,638)$

'The doctrine he controverts, though true, is not the whole truth. (...) there are cases which it does not reach' (ibid., 641).

Moreover, Mill accounts for these anomalies by hypothesizing particular shapes of the curves of demand and supply that could make them arise: ${ }^{6}$ the abandonment of the classical theory of value is complete.

In 'Mr Mill's Theory of Value', Marshall provides his interpretation of Mill's theory. His emphasis is on the demand side while the cost of production has a subordinate role: 'Some persons fail to see that (..) [Mill's] "Law of Cost of Production" is regarded by him as operative only as a result of, or a corollary from, the law according to which the action of the producers of a commodity is governed by their calculations of the circumstances of the future supply and demand in the market.' (Marshall, 1876, 127) He rejects the identification between Mill's theory and the law of the cost of production: 'I propose, then, to speak of the form of exposition of Mill's central doctrine, (...), as " The Law of Free Production and Average Demand" (...); and to speak of Mill's Laws of Cost of Production (...) as corollaries from it'. (ibid., 128) The equality between supply and demand has to be considered the general law of value: '.. we are to regard the average exchange value as under normal circumstances equating supply and demand.' (ibid., 129)

Right before stating the law, Marshall reminds us that Mill had conceived demand as a function of price, but instead of confining this law to the case of non-reproducible goods, he says: 'Although Mill puts this statement in the most prominent place possible, and repeats it, some of his critics have not seen its full force.' (ibid., 129) Marshall captured the force and the importance of demand as a function of price. In the Principles he generalized its application to all the possible market situations, which are not distinguished by the kind of good but by the time allowed for the equalization between demand and supply.

We saw that in classical political economy supply conditions regulated normal value. With Marshall, the demand side obtains an equal and symmetric role as supply in determining the value of a good. Clearly, in order for this to be

\footnotetext{
${ }^{6}$ Most of the examples proposed by Thornton can be understood as cases where supply and demand functions are discontinuous. Indeed Mill notices: 'either the demand or the supply advanc $[\mathrm{e}]$ or reced [e] by such violent skips, that there is no halting point at which it just equals the other element'. (Mill, 1869, 641)
} 
possible in a framework of simultaneous determination of prices and quantities, a non-constant relation between cost and amount produced is required. Demand would otherwise merely determine the quantity produced with no effect on value.

If, as Shove speculated: '. . Marshall began with the objective demand and supply schedules, the phenomena of the market place, and worked back from them to their psychological basis, not (...) the other way about' (Shove, 1942, 307), it is worth analyzing how Marshall, after building the industry supply curve, tried to substantiate it with the analysis of supply at the individual producer level.

\section{Marshall and Cournot ${ }^{7}$}

In analyzing Marshall's economic formation and apprenticeship the role of Cournot and von Thünen stand right after the classical tradition; at least, they are the economists Marshall is most willing to acknowledge his intellectual debt to. In particular, they are fundamental in the development of the notion of equilibrium as balance at the margin between benefits and costs. In the Preface to the first edition of the Principles (1890) Marshall writes: 'Under the guidance of Cournot, and in a less degree of von Thünen, I was led to attach great importance to the fact that our observations of nature, ..., relate not so much to aggregate quantities, as to the increment of quantities, and that in particular the demand for a thing is a continuous function, of which the "marginal" increment is, in stable equilibrium, balanced against the corresponding increment of its cost of production'. (I: $\mathrm{x}$ )

In his own reconstruction, Marshall estimates he 'read Cournot in 1868' (Pigou, 1925, 413). ${ }^{8}$ As we saw, Cournot had a neat formulation of perfectly competitive equilibrium based on the equality between price and marginal cost, where the industrial marginal cost is obtained as the horizontal sum of the individual ones. We aim at investigating two strongly intertwined issues. First, to what extent Marshall shared this notion of competitive equilibrium and, second, why he avoided the analysis of individual producer until the first edition of the Principles even though he had known Cournot for so long.

Accepting Cournot's competitive analysis was problematic for at least three reasons: the existence of a surplus of revenues over costs in equilibrium, the independence of the cost structure from aggregate production (i.e. external (dis)economies), the conclusion that competition and increasing returns were incompatible.

\footnotetext{
${ }^{7}$ From now on, unless otherwise stated, all references to Marshall are taken from 'Marshall, A. (1920) Principles of Economics, ninth (variorum) edition, Guillebaud ed., 2 vols. London: Macmillan, 1960'.

${ }^{8}$ A pre-1870 dating for Marshall's knowledge of Cournot is confirmed both by Groenewegen $(1995,150)$ and by Whitaker (in Marshall, 1975, II: 240).
} 
An annotation of Marshall's copy of Cournot reads: '..he points out the terrible result $\mathrm{w}^{\mathrm{h}}$. would arise if the total demand price fell short of the total supply price. But he seems to see no objection to its falling short. Yet from the point of view of normal theory one plan is as bad as the other.'(Marshall, 1975, II: 305). The same concern is voiced a few years later in a fragment whose more plausible attribution is 1874 : '[Cournot] however says that $\phi^{\prime \prime}\left(x_{k}\right)$ must be positive; because if it were not $x f(x)$ would be less than $\sum \int \phi^{\prime}\left(x_{k}\right) d x_{k}$ [i.e. $\left.\sum \phi\left(x_{k}\right)\right]$. That it to say the trade would be carried on at a loss. He does not see that there is an equal objection to its being greater' (ibid., II: 305) (with $\phi($ ) and $f()$ being respectively total cost and demand price as a function of output). Years later, in a letter of 1888 to J.N. Keynes he refers to the same fragment by noticing that he had 'gone at some length into the question whether the marginal expenses of production is to be regarded as $\phi(x) \Delta x$ or as $\Delta(x \phi(x))$ where $y=\phi(x)$ is the equation to supply curve, $y$ being the price $\& x$ amount of commodity' (ibid., II: 302). The question Marshall had been asking was whether the marginal expenses of production are given by the average cost at the margin or by the increment in total cost. ${ }^{9}$ In a related manuscript fragment, probably later than 1874 , he had clearly implied that it is average cost which has to be considered as equaling the marginal expenses of production: '..in the economic supply curve ... $x y$ ( $y$ being the expenses of production on the margin) is the only definition available of aggregate expenses of production.' (ibid., 302 n.) From this account, it emerges that Marshall, much in the classical spirit, demands the absence of profits from a position of equilibrium; and that he saw clearly that increasing costs are problematic from this point of view. Cournot's equilibrium analysis lacks a time dimension, and such absence is responsible for the existence of equilibrium profit: marginal cost pricing was not a feasible option until the distinction between short and long term, and the related notion of quasi rents as temporary excess of revenues over costs would be elaborated. ${ }^{10}$ It is worth noting that a constant returns technology, the obvious candidate to reconcile marginal and average costs, could not be considered by Marshall as it was in clear conflict with his attempt to establish a role for demand in determining normal value.

In the 1874 fragment we referred to, Marshall seems to attribute the whole difference between marginal and average cost to the existence of external diseconomies. In fact, he rejects marginal cost pricing not only because it would lead to excess profits, but also because it would imply that the producer would have to 'take into calculation the indirect results of his action on the expenses of producing the whole supply' (ibid., 303). Marshall fails to note that with individual increasing cost, which is Cournot's assumption, marginal cost exceeds average cost for any level of production even without externalities. However, the point sheds light on Marshall's dissatisfaction for making costs dependent

\footnotetext{
${ }^{9}$ Notice the change in notation: in the first quotation $\phi(x)$ represents total cost of producing $x$, in the second it is the supply price.

${ }^{10}$ Given this account, Marshall's claim of having developed the doctrine of quasi-rents seems unlikely: 'I may say that my doctrine of quasi-rents, ..., took substance in 1868'. (Marshall, $1925,412)$
} 
merely on individual output: '[Cournot] has supposed that each ones production is independent of each other person;...But then $\phi^{\prime}\left(x_{k}\right)$ depends entirely on the accidents of individual $k$, with wh. economics has nothing to do' (from Marshall's copy of Cournot, ibid. 305).

Finally, Cournot had adopted the assumption of increasing costs to avoid that his analysis would lead to the extinction of competition in favor of monopoly. His solution looked particularly unsatisfactory to Marshall who was strongly aware of the relevance of the increasing returns in the manufacturing industry: 'My confidence in Cournot as an economist was shaken when I found that his mathematics re I.R. (increasing return) led inevitably to things which do not exist and have no near relation to reality.' (letter to Flux $7 /$ iii/1898, in Pigou, A.C. ), (1925), 406-7) Such dissatisfaction spurred Marshall's search for economic reality ('my Wanderjahre among factories...to discover how Cournot's premises were wrong') which produced what he deems his solution to the problem of increasing returns: 'The chief outcome of my work in this direction, which occupied me a good deal between 1870 and 1890, is in the Representative firm theory, the supplementary cost analysis, as well as the parts that directly relate to supply price for I.R'. (ibid. p.407) It seems plausible that Marshall waited until he found what considered satisfactory solutions to Cournot's shortcomings before developing the equilibrium analysis as balance at the margin between benefits and costs: 'his failure contributed to make me hold back most of my diagrams as to value from formal publication for twenty years' (II: 69). In the next section, we investigate the evolution of Marshall's treatment of supply and competition.

\section{Marshall on competition and supply}

\subsection{Competition}

The first printed exposition of Marshall's theory of value can be found in The Pure Theory of Domestic Value (1879a). Around 1873 or 1874 Marshall began to work on the composition of a volume on international trade; the work was later abandoned due to Marshall's illness but Henry Sidgwick obtained permission to print some chapters of it for private circulation in Cambridge: chapters $\mathrm{V}$ and VI constituted The Pure Theory of Domestic Value. ${ }^{11}$ The object of the book is to 'determine the relative values of commodities produced in the same country under the action of free competition.' (Marshall, 1879a, 1) The analysis is carried out in the partial equilibrium approach by means of diagrams. The

\footnotetext{
${ }^{11}$ These chapters were widely known in Cambridge as a manuscript at least since 1875 . According to Keynes: 'These must have been substantially complete about 1873 and were communicated to his pupils (...) about that date' (Keynes, 1924, 332); Whitaker instead notes: '..the Pure Theory of Domestic Value, probably written around 1875' (Marshall, 1975, I: 49). Moreover, The Pure Theory heavily relies on the unpublished 'Essay on Value', which was probably completed in 1870 or 1871 (Whitaker: '..the Essay should have been composed in 1870, or perhaps 1871' (Marshall, 1975, I: 120).
} 
normal value is determined as the intersection between demand and supply functions. ${ }^{12}$ Free competition has a central role as it is responsible for the enforcement of the tendency of demand price and supply price to a common value ('the great central law of economics' (ibid., 3)). It is described along classical lines: if demand price exceeds supply price, producers will earn more than the normal rate of profit, new capital will enter that trade to re-establish normal profitability. While the value theory is changing towards demand and supply approach, the notion of competition is unaffected.

In The Economics of Industry (1879b), Marshall and Paley Marshall adopt a similar notion of competition. In the preface to the second edition of his book (1881), they provide us with a definition:

'A man competes freely when he is pursuing a course which without entering into any combinations with others, he has deliberately selected as that which is likely to be the greatest material advantage to himself and his family (...). Normal results in Economics are therefore those which would be brought about in the long run by this active principle, if it had time to overcome (...) - custom, inertness, ignorance, and all the other passive elements which make up economic friction.' (Marshall and Paley Marshall, 1879b, vi) The coincidence between competition and normality must be emphasized as it will be later rejected. However, at this stage of his intellectual development, economic analysis, for Marshall, should be concerned with results emerging when the action of competition is free to operate. When the access to production is 'free for everybody', the principle of competition is effective and the normal value of a good can emerge.

The Principles retain this conception but with one fundamental change. In the introduction (I, i, 4) Marshall defines competition as 'the racing of one person against another, with special reference to bidding for the sale or purchase of anything.' (I: 4). This implies that when analyzing the normal value of a good under competitive conditions, (V, iii), he assumes that 'there is no close combination among dealers on either side, but each acts for himself, and there is much free competition; buyers generally compete freely with buyers, and sellers compete freely with sellers' (I: 284). Competition then demands the pursuit of self-interest and it is the 'active force' (I: 287) which guarantees the amount produced to be the one which brings about the equilibrium between normal demand and normal supply. However, the position held in (V, iii) has to be considered only as a provisional assumption, and it is in fact rejected in the rest of the Principles. An annotation on an 1886 Marshall copy of Economics of Industry is instructive of such change; it reads: 'Be careful to strike out everything wh. implies that normal value=competitive value' (Marshall, 1975, I: 73 n.). Such warning has been seconded in several instances in the Principles:

\footnotetext{
${ }^{12}$ In developing his geometrical illustration of supply and demand Marshall was influenced by German 19th century economic school, Rau and Mangoldt in particular. (see Groenewegen, 1995, 153-4) On the contrary, Marshall always denied any influence of Jenkin ('..evidence on dating is insufficient to justify Marshall's claim that he anticipated Jenkin, but there is nothing in the annotations making such a claim inherently implausible', Whitaker in Marshall, 1975, II: 241$)$
} 
'Of course Normal does not mean Competitive. Market prices and Normal prices are alike brought about by a multitude of influences...of which some are competitive and some are not' (I: 347, appeared in 1907, 5th edition). Marshall himself recognized such a change in a letter to J.B. Clark, written in 1902: 'I then believed it was possible to have a coherent though abstract doctrine of economics in which competition was the only dominant force; and I then defined 'normal' as that which the undisturbed play of competition would bring about: and now I regard that position as untenable' (quoted in Guillebaud, 1952, 122).

A possible guess which may be ventured to rationalize the coexistence of the two conflicting claims is that Marshall proposes two distinct analyses of markets equilibrium: a formal one which can be represented in mathematical terms, assumes 'much free competition' and applies only under certain conditions ('neglecting those features which are special to particular parts of economic science', I: 341); and a general one, more 'in accordance with the actual facts of life' (I: 341 ), which captures all the elements determining the true normal value of a commodity. In Section 5.3 we will analyze both in some detail.

\subsection{Supply in the Early Writings}

We have emphasized that Marshall, in his interpretation of the Classics, established a symmetric role of demand and supply as determinants of value. In a famous analogy, demand and supply are compared to two "blades of a pair of scissors' of which it cannot be said which is the cutting one. A non-constant supply curve is a necessary condition for such symmetry to be possible; indeed, according to Marshall, Ricardo's mistake consisted of assuming constant costs even though he was aware of the laws of decreasing and increasing returns.

Since the early writings, Marshall analyzed the forces underlying the nonconstant behavior of the supply curve. In The Pure Theory supply is characterized as the set of unit prices that cover the expenses of production, i.e. an average cost curve. It is governed by the law of variable returns. Typically, raw materials are subject to decreasing returns as nature offers limited endowments of resources; manufactures, where most economies of production are to be found, are mostly subject to the law of increasing returns. The expansion of the whole market, i.e. the industry, is a necessary condition for the availability of economies of scale. The increase in industry's output necessary to bring about these economies can be satisfied both by increasing the scale of the single firm and by the aggregation into one district of a large number of small firms: '..the advantages which are generally classed under the heads of the division of labour and production on a large scale can be attained almost as fully by the aggregation into one district of many establishments of a moderate size as by the erection of a few huge factories' (Marshall, 1879a, 8).

The treatment of division of labor in The Economics of Industry, (I, viii), develops along similar lines. The extent of the market is the necessary condition for economies of scale to arise. The question to address is whether these advantages depend on the scale of the firm; many of these economies are not 
specific to large firms but can be also obtained by small factories. This can occur 'provided that there are a very great number of them in the trade' (I, viii, $\S 4,52)$. When demand is high, the process of production can often be divided into several stages of production, some of which can be performed by Subsidiary Industries, with small-scale factories. However, 'small factories, whatever their numbers, will be at a great disadvantage relatively to large unless many of them are collected together in the same district' as they can exploit 'the advantage of the Localization of Industry' (ibid., 53). Marshall relies on external economies to face the problem of increasing returns. ${ }^{13}$

\subsection{The Principles and the individual producer}

IN the 'Principles' Marshall introduced the key elements of his theory of the individual firm: the principle of substitution, the distinction between short and long run, the prime and supplementary cost concepts, and the representative firm. I will try to show in what follows the complexity of Marshall's analysis and how a particular interpretation of his work led to the notion of long run partial equilibrium we are now familiar with.

\subsubsection{The formal analysis}

Marshall's analysis of the individual producer is based on the principle of substitution among methods of production. Marshall claimed he had derived this principle by the beginning of the 1870 s when his theory of distribution was almost fully developed. ${ }^{14}$ However, it is only with the Principles that we find its application to the theory of the firm.

The principle of substitution contends that firms will adopt the method capable of producing a given amount of good at the lowest cost:

'... [producers] in each case choose those factors of production which are best for their purpose; the sum of the supply prices of those factors which are used is,

\footnotetext{
${ }^{13}$ Marshall's external economies seem to pertain more to the whole economy rather than to a single industry. Stigler notices: 'Marshall's external economies form an essentially historical category. The development of knowledge and invention, cross-fertilization, the emergence of subsidiary firms to exploit by-products and to supply equipment, the accumulation of skilled labour, all are characterized by growth.' (Stigler, 1941, 71)

14 'Before 1871 (...) I had worked out the whole skeleton of my present system in mathematics though not in English. (...) Notes XIV-XX were evolved in substance about same time. These contained the substance of my doctrine of Substitution; though I did not make use of that term till long after. (..) the one book which really guided me was written by (..) von Thünen' (Marshall, 1975, 38). Thünen seems the only economist Marshall is willing to acknowledge in his development of the marginal theory of distribution; Walker's influence was strongly denied (see Marshall, 1925, 416). See Groenewegen (1995, 151) on how such emphasis on Thünen's relevance relates to Marshall's claims to independent development of marginalism. Whitaker doubts that Marshall had worked out already in 1869 a theory of distribution based on the marginal productivity. After exposing large evidence for supporting his point (see Whitaker, 'The Formation of Marshall's Economic Doctrines, 1867-73' in Marshall, 1975, 37-52) he concludes : 'the theory of distribution remained imperfectly settled in Marshall's mind even after 1876, so that he had remained reluctant to write about it in the Economics of Industry, "because I did not then see my way clearly as to some parts of it" (with I referring to Marshall)' (51-2).
} 
as a rule, less than the sum of the supply prices of any other set of factors which could be substituted for them; and whenever it appears to the producers that this is not the case, they will as a rule, set to work to substitute the less expensive method. (...) We may call this (...) The principle of substitution' (I: 284). As of how much to produce the entrepreneur 'pushes the investment of capital in its business in each several direction until what appears in his judgment to be the outer limit, or margin, of profitableness is reached; that is, until there seems to him no good reason for thinking that the gains resulting from any further investment in that particular direction would compensate him for his outlay' (I: 356, 359). Indeed, the choice of the cheapest method of production and of the limit of production are not independent as the principle of substitution is connected to the tendency to diminishing returns: 'This principle of substitution is closely connected with, and is indeed partly based on, that tendency to a diminishing rate of return from any excessive application of resources or of energies in any given direction' (I: 356). At this stage (V,iv) Marshall is carrying on his analysis under the provisional assumption of 'much free competition', which, as we noted above (cfr. supra § 5.1), he described along classical lines and identified with freedom of entry. At the same time, in discussing the problems related to the investment and distribution of resources he suggested (I: $357 \mathrm{n}$.) to read the text in connection with Note XIV of the Mathematical Appendix. In the note, which appeared in the third edition (1895), Marshall adopts the language of differential calculus to state that profit maximization will imply the equality between marginal outlay $(V)$ and marginal receipts $(H)$ for any agent of production $\left(\frac{d V}{d x_{i}}=\frac{d H}{d \beta_{j}} \frac{d \beta_{j}}{d x_{i}}\right.$, where $x$ is an agent of production and $\beta$ is the particular use in which the agent is employed). Here Marshall is explicitly adopting Cournot's principle of equality between marginal revenue and marginal cost. Even more, he clearly states the equality between marginal revenue and demand price: 'If ... an individual undertaker produced $Q^{\prime}$, a thousand[th] part of $Q$ then the increased receipt from putting on an additional man is $p \Delta Q^{\prime}, \ldots$; and the deduction to be made from it is only $Q^{\prime} \Delta p$, which is a thousand part of $Q \Delta p$ and may be neglected. For the purpose therefor[e] of illustrating a part of the general action of the law of distribution we are justified in speaking of the value of the net product taken at the normal selling value of the product, that is, as $p \Delta Q^{\prime}$ (I: 850). At least beginning with 1895 he provides an explicit example of perfect competition and marginal cost pricing. ${ }^{15}$ By suggesting reading jointly $(\mathrm{V}$, iv) and note XIV, Marshall established a connection between free and perfect

\footnotetext{
${ }^{15}$ In light of the last quote, claims that Marshall never adopted perfect competition are surprising: 'But Marshall nowhere assumes a horizontal demand curve' (Maxwell, 1958, 694); 'It is true,..., that Marshall has nowhere committed himself in words to the completely horizontal [demand curve] of a perfect market..' (Robertson, 1956, 18-9). See also Wolfe (1954, 341). Questioning the relevance of perfect competition for the Marshallian industrial analysis seems a more tenable option: 'Beginning with the third (1895) edition, (..) [Marshall] explicitly introduced the horizontal demand curve for individual firm as the normal case and gave it the same mathematical formulation as did Cournot. But these were patchwork revisions, and they were not carried over into the many passages where looser concepts of competition had been employed.' (Stigler, 1957, 10)
} 
competition, which, though clearly distinct, coexist in the formal analysis of investment and distribution. ${ }^{16}$

Understanding under what circumstances Marshall deems perfect competition the applicable case is utterly important. This would happen when the individual [producer] is only one of many who have efficient, if indirect, access to the market' (I: 850); on the contrary, he excludes the cases of producers with 'limited trade connection' possibly afraid of 'spoiling their special markets', the cases of 'commercial depression' and those where 'expenses of production diminish rapidly with every increase in the amount produced' (I: 849). Since these are the cases that Marshall analyzes in depth when dealing with the manufacturing sector, the joint reading of chapters iii, iv of book V and note XIV seems to indicate that perfect competition and marginal cost pricing apply to the agricultural and raw materials sectors where the limited land would guarantee the presence of decreasing returns. ${ }^{17}$ Notice that the margin of production depends on aggregate production: contrary to Cournot, there exist external diseconomies and, in turn, costs do not depend on individual production only. The existence of increasing costs does not pose the problem of excess profits characterizing Cournot's equilibrium; decreasing returns are due to the existence of a factor available in fixed quantity and any excess of revenues over outlays would be absorbed in the form of rent.

The solution to such problem for the case where no scarce resources were involved in production required the development of the distinction between short and long run and of the concept of quasi rents.

\subsubsection{Short period}

The short period is defined as the time during which 'people take the stock of appliances of production as practically fixed' (I: 374). In assessing short-run production decisions, the distinction between prime and supplementary cost is relevant. Prime, or special or direct, cost is the share of cost that can be entirely imputed to a certain unit of production: typically, it can be considered as constituted by the cost of raw materials, labor and wear- and- tear of plants. Supplementary costs cover the general expenses of the business inclusive of the interest on fixed investment. Under normal conditions, any producer expects to charge a price covering both the prime and supplementary costs, but in the short run, the 'lowest price at which it will be worth his while to accept an order' (I: 360) is regulated by the prime costs. In fact, this would be the case

\footnotetext{
${ }^{16}$ Hart $(1996,360)$ argues that 'even within the confines of 'free competition', the market structure being analysed differs markedly from the large numbers, homogenous product concept'. His case is supported by Marshall insisting that 'we do not assume that competition is perfect' (1920, I: 540). However, as Hart himself notices, Marshall identifies perfect competition with perfect knowledge; therefore his rejection of perfect competition does not necessarily rule out the case of negligible size firm. We think the evidence we provided supports the simultaneous adoption of classical and perfect competition. We should notice that such result conflicts with McNulty's claim of incompatibility between the two notions of competition (cfr. supra Section 2).

17 'The expenses of production of any amount of a raw commodity may be best estimated with reference to the 'margin of production' at which no rent is paid' (I: 339, n.1).
} 
only if producers were not afraid of spoiling the markets by accepting too low prices. Each producer sells both in a particular and in a general market, and '[he] fears to spoil his chance of getting a better price later on from his own costumers; or, if he produces for a large and open market, he is more or less in fear of incurring the resentment of other producers, should he sell needlessly at a price that spoils the common market for all' (I: 374). This is the reason why, in general, marginal cost pricing does not apply: 'the true marginal supply price for short period...is nearly always above, and generally very much above the special or prime cost...which is immediately and directly involved by getting a little further use out of appliances which are not fully employed' (I: 374-375). The latest quote gives strong support to those interpreters who, even for the short period, deny that Marhall adopted marginal cost pricing and who stress, on the contrary, the non marginalistic elements of his analysis of markets. ${ }^{18} \mathrm{~A}$ few lines before, Marshall describes the relation between price and supply as follows: 'As the expectations of price improve, an increased part of the production will yield a considerable surplus above prime costs, and the margin of production will be pushed outwards. Every increase in the price expected will, as a rule, induce some people who would not otherwise have produced anything, to produce a little; and those who would have produced something for the lower price, will produce more for the higher price. That part of their production with regard to which such persons are on the margin of doubt as to whether it is worth while for them to produce it at the price, is to be included together with that of the persons who are in doubt whether to produce at all; the two together constitute the marginal production at that price.'(I: 373) A famous interpretation proposed by Frisch goes in the direction of reconciling Marshall's description of short period with Cournot analysis. Individual supply would 'coincide with the marginal cost curve' (Frisch, 1950, 501, italics in the original) and the 'supply schedule of the market .. [would be] derived .. by horizontal addition of the individual supply curves' (ibid., 504). Only when expected prices are too low firms would adopt a restrictive strategy by suspending production for fear of spoiling the market. While it seems plausible that the cost structure is rising, it seems doubtful that at this point Marshall was trying to derive aggregate supply as the horizontal sum of individual supplies. As we saw, the identification between marginal cost and supply curves depends on the adoption of perfect competition so that firms act as 'quantity adaptor' (ibid., 501). Quantity adapting behavior however, is at odds with Marshall's preference for referring to the supply price of a certain quantity rather than to the quantity supplied at a given price ('the price is that the expectation of which is sufficient and only just sufficient to make it worth while for people to set themselves to produce that aggregate amount', I: 373). Second, Marshall utilized the fish market as an illustration of the functioning of

\footnotetext{
${ }^{18}$ Robertson (1956) and Andrews (1951) are two of the most eminent scholars sharing this opinion. According to the former Marshall's use of the term 'marginal' is misleading and it would not imply the equality of price and the marginal cost of firms (1956, p.14). For Andrews (1951, p. 148) Marshall did not identify cost and supply curves. See also Williams (1978, 88-90, 106), O’Brien $(1990,69,78)$, and Hart $(1996,354)$.
} 
short period supply (I: 370). He clearly showed that at least part of the increasing costs is due to external effects: higher wages for sailors and the use of less efficient boats depend on the aggregate production of the industry. All that can be said is that supply for the short period is upward sloping 'even as regards industries which in the long period follow the tendency to increasing returns' (I: 370) because, as Williams suggests, 'starting from a position of industry equilibrium producers will only be willing to expand production if offered a higher price'. (Williams, 1978, 90)

In the short period analysis, Marshall develops the concept of quasi-rent. It is the 'surplus of total receipts over prime cost' (I: 377) when appliances of production are fixed; as such it partakes both of the nature of interest and of rent. Being a surplus of revenue over cost, i.e. the income earned on an investment of capital, it resembles the category of profits, but since its source is the scarcity, or fixed availability, of a particular capital good it has the nature of rent. Just like rent, as stressed by Guillebaud $(1952,125)$, it is a price-determined and not a price-determining class of income: 'Variations in the particular income derived from [those appliances]...do not directly affect the price of commodities produced by them.' (I: 376-7) Marshall carefully analyzed its similarities and differences with interest and rent. On the one hand he notices: 'That which is rightly regarded as interest on 'free' or 'floating' capital, or on new investment of capital, is more properly treated as a sort of rent - Quasi-rent- on old investment of capital' (I: 412); on the other hand the relation between rent and quasi rent depends on the different nature of land and appliances: while 'land...is..a permanent and fixed stock' appliances 'are a practically fixed stock for short periods'. (I: 431-2) Quasi-rents are temporary rents, which gradually shade into interest on floating capital as we move from short to long period analysis. The new concept allowed Marshall to reconcile the existence of a surplus of revenues over costs on the non-marginal lines of production with the classical notion of equilibrium where profits are absent.

\subsubsection{Long period}

When Marshall turned to the long period analysis of supply for the manufacturing sector, he had to solve the third of the problems raised by Cournot analysis, namely the reconciliation of competitive conditions and increasing returns. Since the early writings Marshall underlined the relevance of external economies in accounting for a decreasing industry supply price; however, contrary to Cournot, he would not deem competition and unexhausted internal economies as incompatible. Marshall's solution is based on the concept of representative firm and the related idea of life cycle of the individual firm.

The representative firm 'must be one which is managed with normal ability, and which has normal access to the economies external and internal, which belong to that aggregate volume of production. ... [it] is that particular sort of average firm at which we need to look in order to see how far economies, internal and external, of production on a large scale have extended generally 
in the industry and country in question'. (I: 264-5) It is the tool by which the normal cost and normal supply price of a given aggregate volume of production are illustrated; from this point of view it is simply an explanatory device, 'a small-scale replica of the supply-curve of the industry as a whole' (Robertson, 1930, 89), or 'a miniature illustration of the supply side'. (Frisch, 1950, 512) There is no attempt to derive industry supply conditions from the behavior of the individual producer. As Marshall comments: '...the history of the individual firm cannot be made into the history of an industry any more than the history of an individual man can be made into the history of mankind. And yet the history of mankind is the outcome of the history of individuals; and the aggregate production for a general market is the outcome of the motives which induce individual producers to expand or contract their output.' (I: 380). However, the representative firm is much more than a mere illustration of general supply conditions. Its fundamental role can be appreciated by observing when Marshall introduces it. It appears in (IV, xiii) where he summarizes the results obtained for the law of increasing and decreasing returns. He considers the possibility that internal economies may lead to the extinction of competition: 'The increase in the scale of [an able man's] business increases rapidly the advantages which he has over his competitors, and lower the price at which he can afford to sell. [..] and if [this process] could endure for a hundred years, he and one or two like him would divide between them the whole of that branch of industry in which he is engaged' (I: 315). In order to deal with the problem Marshall turns to the famous metaphor of the trees in a forest ('But here we may read a lesson from the young trees of the forestas', I: 315). Just like the trees of a forest, firms have a regular life cycle, which implies beginning small and weak, slowly increasing their market shares and access to internal and external economies, peaking and gradually declining. In equilibrium, while each individual firm is going through its life cycle, the age distribution of the firms population is stable so that the representative firm keeps its size and cost structure constant. The effectiveness of the life cycle in preventing a firm from accessing all the available internal economies, thus monopolizing the market, depends on the relatively long time required to build up internal economies as compared to the duration of the managerial skills of the entrepreneur. In turn, the plausibility of the life cycle seems to depend on two conditions: on the one hand, increasing sales must take time so that the acquisition of internal economies is limited by the difficulty of marketing additional production; this requires that products be not homogenous. On the other hand, a high level of managerial skills cannot be maintained after the firm's founder retired. According to Marshall, the availability of vast economies of scale occurs in those industries where firms are confined to their own market and where a high increase in production could not be easily sold: 'There are many trades in which an individual producer could secure much increased «internal» economies by a great increase of his output; and there are many in which he could market that output easily, yet there are few in which he could do both. And this is not an accidental, but almost a necessary result' (I: 286). Commodities obeying the law of increasing returns are mostly 'specialties' aimed 'at creating a new want' which 'must win 
their way to general favour slowly' (I: 287): increasing returns and product differentiation are explicitly associated. Later on, when studying the normal equilibrium with reference to increasing returns ( $V$, xiii), the idea of a special market is described by an individual demand curve: 'This may be expressed by saying that when we are considering an individual producer, we must couple his supply curve - not with the general demand curve for his commodity in a wide market, but- with the particular demand curve of his own special market. And this particular demand curve will generally be very steep; perhaps as steep as his own supply curve is likely to be, even when an increased output will give him an important increase of internal economies' (I: $458 \mathrm{n}$.). Anticipating the analysis of imperfect and monopolistic competition, Marshall introduced the notion of a downward-sloping individual demand curve to deal with increasing returns. However, contrary to subsequent developments (see Triffin 1940), it did not imply the abandonment of the notion of industry which is to be understood in a broad way as encompassing producers selling in their own particular market but still operating under competitive conditions. ${ }^{19}$ As of the second condition, Marshall became progressively aware that the natural decay of a firm could be compromised by the existence of joint stock companies. In the first edition of the Principles (1890), where the life cycle is put forward for the first time ('And as with the growth of trees, so it is with the growth of business', II: 343), he already felt the need to qualify the theory by noticing: 'There is no rule of universal application; but the struggle between the solid strength of steady-going firms with the large capitals on the one hand, and the quick inventiveness and energy, the suppleness and power of variation of their smaller rivals on the other, seems inclined to issue in the large majority of cases in the victory of the former.' (II: 345 ). With time his skepticism grew to the point that from the sixth edition on (1910) the analogy between firms and trees is said to be valid only before the development of joint-stock companies: 'And as with the growth of trees, so was it with the growth of businesses as a general rule before the great recent development of vast joint-stock companies, which often stagnate, but never die.' (I: 263). However, despite this admission, he defended the life cycle theory until the final edition of the Principles: 'If [the guidance of the business] is turned into a joint-stock company, it may retain the advantages of division of labour $[\ldots]$. But it is likely to have lost so much of its elasticity and progressive force, that the advantages are no longer exclusively on its side in its competition with younger and smaller rival' (I: 263-4). It is only with the appearance of Industry and Trade (1919), the long awaited volume on 'Superstructure', that the life cycle is finally abandoned: 'A private firm without great vigour is sure to die: a large joint stock company has special advantages, many of which do not materially dwindle with age. ... And, even if it be somewhat lacking in energy and initiative, it can often utilize...new ideas and new appliances that have been created by independent workers: and it has special opportunities for the introduction of new blood into its management' (Marshall, 1919, 316)..$^{20}$

\footnotetext{
${ }^{19}$ See Hague (1958) on the difficulties connected to the coexistence of particular markets and competition.

${ }^{20}$ See Whitaker (2003) on the evolution of the role of joint stock company in Marshall.
} 
The last edition of the Principles is one year older than Industry and Trade; the fact that Marshall retained the life cycle even at a point when he thought it did not apply anymore confirms how fundamental the concept was to the validity of his theory of normal supply.

Since the second edition (1891) of the Principles, Marshall introduced the notion of particular expenses (PE) curve to represent cost and supply conditions when the 'general economies of production [are taken] as fixed and uniform' at the level corresponding to the equilibrium output (I: 811). Following Whitaker $(1990,39)$ we can interpret it as a curve arraying 'the total output of the various firms by current average cost'; since economies of scale are fixed and costs incurred by firms of different ages are ordered by decreasing efficiency the PE curve is upward sloping even for the case of an increasing returns industry. The stage of the life cycle reached by a firm determines the cost of production and the market share of each firm; in turn, production is not pushed to the point where marginal cost equals price. Marshall indeed is adamant that by long period marginal supply price he does not mean the rate of increase of total cost, i.e. marginal cost, but 'Total Cost of production at the margin' (letter to Edgeworth 1892, in II: 810), which is to be understood as the unit cost of equilibrium output, or the average cost of the representative firm. ${ }^{21}$ The development of the $\mathrm{PE}$ curve to complement the supply curve helps understanding why for the case of increasing returns 'the term «margin of production» has no significance' and why, on the contrary, 'the cost of a whole process of production, without any attempt to isolate that of a single commodity' (I: 805) should be considered. In turn, it helps avoiding what had been Cournot's fundamental mistake: '..Some among whom Cournot himself is to be counted, have before them what is in effect the supply schedule of an individual firm; representing that an increase in its output gives it command over so great internal economies as much to diminish its expenses of production; and they follow their mathematics boldly, but apparently without noticing that their premises lead inevitably to the conclusion that, whatever firm gets a good start will obtain a monopoly of the whole business of its trade in its district.'(I: 459, n.) Regardless of how successful the concepts of representative firm and life cycle as solutions to the problem of increasing returns are considered, ${ }^{22}$ it is clear that they led Marshall's analysis of long run equilibrium for the case of increasing returns industries far away from

\footnotetext{
${ }^{21}$ In Manuale di Economia Pura (1889) Pantaleoni reproduced the diagrams of supply curve put forward by Marshall in the The Pure Theory. As we saw, these diagrams represent supply as expenses per unit of output, or average cost, curves. In the English version, Pure Economics $(1898,192$, n.) Pantaleoni suggested that Marshall should substitute a marginal expenses curve to the expenses per unit curve in order to represent supply. Since Pure Economics follows the third edition of Marshall's Principles he clearly implied that marginal cost curve was extraneous to the Principles. We know that Pantaleoni visited Marshall in Cambridge (see Groenewegen, 1995, 244) but unfortunately no correspondence between them has survived. (see Whitaker, 1996, 283, n.) Marshall however, did not follow Pantaleoni's advice in the following editions of the Principles. In turn, we are inclined to think he did not consider marginal cost as a solid basis for long period supply curve.

${ }^{22}$ See the 1930 symposium hosted by the Economic Journal with Sraffa and Robertson as respectively the main critic and defender.
} 
Cournot's notion of marginal cost pricing.

The compatibility between competition and increasing returns is only one aspect of a more general reconciliation problem that Marshall attempted to handle with the aid of the representative firm. Marshall's interpreters (see among the others Hart 1991, 1996, 2003; Groenewegen 2003 and Quéré 2003) have recognized a fundamental difference in scope and methodology between book IV and $\mathrm{V}$ of the Principles. Book four studies 'the mechanisms that conduct the dynamics of industrial organization' (Quéré, 2003, 183); such dynamics is highly irreversible and increasing returns are its fundamental driving force. Book five, on the contrary, is concerned with static equilibrium of normal demand and supply. Mechanical analogies, like 'a stone hanging by an elastic string' (323) or a pendulum, are appropriate for the static equilibrium framework, but the study of increasing returns belongs to those 'higher stages of our work' (323) which cannot be explained with the help of mechanical equilibrium but need be analyzed by means of biological analogies. The influence of social evolutionary thinkers such as Spencer and Hearn on Marshall's thought is well known (see Groenewegen 1995); in fact, he seems to have been increasingly turning to biology throughout the years. Since the fifth edition of the Principles (1907), he introduced in the Preface the famous quote: ${ }^{23}$ 'The Mecca of the economists lies in economic biology rather than in economic dynamics' (I: xiv). The metaphor of the trees of the forest is the biological analogy that allows Marshall to reduce a situation of individual (firms) disequilibrium to aggregate (industrial) equilibrium. By so doing, he attempts 'to construct an equilibrium concept that could be used to shed light on outcomes of processes that are recognized to be continuous and irreversible in time' (Hart, 2003, 1140) and to represent 'within an equilibrium framework, outcomes of 'evolutionary' processes identified directly with the increasing returns and thus the long period industry supply schedule.' (ibid., 1144) Since our focus is merely on the notion of equilibrium price, we need not assess here whether such attempt was a success ('a peculiar triumph in his creation of a unity out of the conceptions of equilibrium and evolution', Shackle, 1965, 36) or a failure ('economic biology remained promise rather than substance', Thomas, 1991, 11). However, the discussion shows that for the case of increasing returns Marshall moved away from the notion of static marginalistic equilibrium.

During the 1920s and 1930s, the analysis of supply took a different direction. Cantabrigian economists, possibly more interested in developing Marshall's theory rather than interpreting it, perfected the notion of perfectly competitive partial equilibrium. In his attack, Sraffa $(1925,1926)$ interpreted Marshall along marginalistic lines. He claimed that economies external to the firm but internal to the industry are the only kind of increasing returns compatible with equilibrium and that, unfortunately, they would be the class of economies most difficult to find in industrial reality. In his reply, Pigou $(1927,1928)$ implicitly accepted

\footnotetext{
${ }^{23}$ The quote was already present in Marshall (1898).
} 
Sraffa's interpretation. In the first place, he objected to Sraffa's dismissal of external economies by defending their relevance and developing the concept of external-internal economies, ${ }^{24}$ i.e. economies internal to the firm that can be only activated by an increase in the size of the market. Second, he turned the 'representative firm' into the 'equilibrium firm', a firm with 'a certain optimum size, trespass beyond which yields no further internal economies' $(1927,195)$. In so doing, even without requiring the equilibrium of each individual firm, Pigou laid the foundation for bringing the Marshallian analysis back to Cournot. ${ }^{25} \mathrm{In}$ the process, two problems were being solved: assuming a $U$-shaped cost curve with the equilibrium firm producing at its minimum eliminated the equilibrium profits; the existence of external economies allowed for the possibility of a decreasing industry supply price. The microfoundation of supply curve under perfect competition was further refined by Kaldor (1934) who suggested a fixed entrepreneurial factor as a rationale for the long run $U$-shape cost curve; and by Robinson (1934) who unambiguously defined perfect competition in terms of an infinitely elastic demand curve. The clearest exposition and systematization of all the possible relations between firm and industrial cost and supply curves has been however elaborated outside Cambridge and it is due to Viner (1931). D. Robertson (1930), who strenuously defended the 'representative firm' as Marshall's authentic solution to the problem of increasing returns, remained at the time an isolated voice.

\section{Average cost and marginal cost pricing: mod- ern developments}

The different nature of pricing rules contained in the Marshallian analysis of competitive markets work can be better appreciated by considering the directions towards which they were respectively developed. Sraffa developed the average cost pricing rule over the course of three decades, which culminated with the publication of Production of Commodities by Means of Commodities in 1960. As is well known, Sraffa $(1925,1926)$ criticized Marshall's long period partial equilibrium analysis of the industry by questioning the logical soundness of the industry non-constant supply curve founded on the production decisions of a price-taking competitive firm. However, he retained the notion of long-run prices as the situation where prices cover the average cost, which is inclusive of the normal rate of profit (see Foley, 2003); as we have seen, this is the equilibrium notion Marshall had borrowed from the classical economists. Sraffa generalized this approach by taking into account the general interdependence of industry structures. Taking the real wage and the scale of production as given, he was able to derive the existence and uniqueness of a vector of relative prices satisfying the requirement of a uniform rate of profit on the value

\footnotetext{
${ }^{24}$ This notion is indeed not extraneous to the Principles: 'But we also expect a gradual increase in demand to increase ... the economies both internal and external'. (I: 460)

${ }^{25}$ Newman $(1960,597)$ notices: "And it was very easy for subsequent workers -and textbooks writers- to substitute ... "each individual firm" for "equilibrium firm" '.
} 
of the capital employed in production. Net output is a given in the analysis so that there is no attempt to jointly determine equilibrium prices and quantities. Marshall, on the contrary, had tried to derive simultaneously equilibrium prices and quantities through the supply and demand approach. As we have seen, in equilibrium, prices should include the uniform rate of profit (interest), which is the price equating demand and supply of capital. This attempt, though, would eventually fail. In fact, during the capital controversy, it was proved that once heterogeneous capital goods are taken into account, the relation between the profit rate determined as the marginal product of capital and the quantity of capital itself violates the fundamental properties required by the marginalistic theory of production and distribution (see for example Garegnani, 1970). The average cost pricing principle based on a uniform rate of profit proved incompatible with the marginalistic approach.

On the other hand, short-run profit maximization, which implies marginal cost pricing, became the basis of the neo-Walrasian intertemporal general equilibrium models (see Arrow and Hahn, 1971). In this framework, when production sets are strictly convex firms earn positive profits as marginal cost is higher than average cost at any level of production. Under constant returns to scale, profits are null. However, the mechanisms enforcing the absence of profits in the neo-Walrasian constant returns case and in the classical case are quite different. In the classical case, given the free mobility of capital, there is a long period tendency of prices towards their average costs of production; in the neo-Walrasian case, the absence of profits emerges instantaneously as the only possibility compatible with finite production plans.

On reflection, it appears that the attempt to elaborate general equilibrium pricing principles in terms of average cost and marginal cost led to the former to return to the classical theory of value and distribution and the abandonment of the absence of profits in the latter. Besides having different origins these two concepts characterizing Marshall's theory of market equilibrium had to part their ways to be fully developed.

\section{Concluding Remarks}

I have tried to show how two different characterizations of equilibrium prices merged in the Marshallian theory of the firm. The equality between price and average cost is the result of competition between firms searching for the highest returns on capital. Marginal cost pricing requires the introduction of the notion of optimal scale of production, that is a scale where costs and revenues on the marginal unit produced are equal. Average cost and marginal cost pricing have quite different origins and two different concepts of competition underlie them. Average cost pricing requires classical competition, that is free entry and exit in the market; marginal cost pricing needs perfect competition: the negligible dimension of the firm prevents it from affecting prices when changing its quantity so that the profit maximizing production requires the equality of marginal cost and price. We saw that Marshall's economic education led him to assume 
the tendency of prices to costs of production as the natural outcome of competition and the obvious starting point for his theory of value. We found only partial support for Marshall's adoption of marginal cost pricing; in particular, we argued that he found it appropriate to describe the agricultural sector and production of raw materials in general. However, he built analytical tools such as the distinction between short and long period, and the notion of quasi rents and external economies, which made it possible for his followers to develop his theory along marginalistic lines, and to provide us with the long run partial equilibrium where price equalizes both average and marginal cost of each individual firm. The attempt of generalizing the analysis to general equilibrium framework shows that the two pricing rule are still difficult to reconcile.

\section{References}

[1] Arrow, K. and Hahn, F. (1971) General Competitive Analysis, San Francisco: Holden-Day.

[2] Backhouse, R.E. (1990) 'Competition', in Foundations of Economic Thought, J. Creedy ed., Oxford: Blackwell.

[3] Blaug, M. (1997) 'Competition as an end-state and competition as a process', in Not only an economist, Chaltenham: Edwar Elgar.

[4] Cournot, A.A. (1838) Researches into the Mathematical Principles of the Theory of Wealth, New York: Macmillan, 1927.

[5] Dardi, M. (1984) Il Giovane Marshall: Accumulazione e Mercato, Bologna: Il Mulino.

[6] Ekelund, R. B. and Hébert, R. F. (1999), 'The Dupuit-Marshall Theory of Competitive Equilibrium', Economica, 66: 225-40.

[7] Frisch, R. (1950) 'Alfred Marshall's Theory of Value', Quarterly Journal of Economics, 64: 495-524.

[8] Garegnani, P. (1970) 'Heterogeneous Capital, the Production Function and the Theory of Distribution', Review of Economic Studies, 37: 407-436.

[9] Groenewegen, P. (1995) A Soaring Eagle: Alfred Marshall: 1842-1924, Aldershot: Edward Elgar.

[10] Groenewegen, P. (2003) 'Competition and Evolution: the Marshallian Conciliation Enterprise', in The Economics of Alfred Marshall, R. Arena and M. Quéré ed., London: Macmillan.

[11] Guillebaud, C. W. (1952) 'Marshall's Principles of Economics in the light of contemporary economic thought', Economica, 19: 111-30. 
[12] Hague, D.C. (1958) 'Alfred Marshall and the competitive firm', Economic Journal, 68: 673-690.

[13] Harris, D.H. (1988) 'On the Classical Theory of Competition', Cambridge Journal of Economics, 12: 139-167.

[14] Hart, N. (1991) 'Returns to Scale and Marshallian Economics', History of Economic Review, 16: 31-79.

[15] Hart, N. (1996) 'Marshall's theory of value: the role of external economies', Cambridge Journal of Economics, 20: 353-369.

[16] Hart, N. (2003) 'Marshall's Dilemma:Equilibrium versus Evolution', Journal of Economic Issues, 37: 1139-60.

[17] Hayek, F. (1948) Individualism and Economic Order, London: Routledge and Kegan Paul.

[18] Kaldor, N. (1934) 'The Equilibrium of the Firm', Economic Journal, 44: 60-76.

[19] Keynes, J. M. (1924) 'Alfred Marshall, 1842-1924', Economic Journal, 34: 311-372.

[20] Marshall, A. (1876) 'Mr Mill's Theory of Value', in Pigou (1925).

[21] Marshall, A. (1879a), The Pure Theory of Domestic Value, London: Macmillan, 1930.

[22] Marshall, A. (1898), 'Distribution and Exchange', The Economic Journal, 8: $37-59$.

[23] Marshall, A. (1919) Industry and Trade; a study of industrial technique and business organization, 4th edn, London: Macmillan, 1923.

[24] Marshall, A. (1920) Principles of Economics, ninth (variorum) edition, C. W. Guillebaud ed., 2 vols. London: Macmillan, 1960.

[25] Marshall, A. (1925) Memorials of Alfred Marshall, A. C. Pigou ed., London: Macmillan.

[26] Marshall, A. (1975) The Early Economic Writings of Alfred Marshall, 186790, J. K. Whitaker ed., 2 vols., London: Macmillan.

[27] Marshall, A. (1996) The Correspondence of Alfred Marshall, Economist, J. K. Whitaker ed., 3 vols. Cambridge: Cambridge University Press.

[28] Marshall, A. and M. Paley Marshall (1879b) The Economics of Industry, 2nd edition, London: Macmillan, 1881.

[29] Maxwell, J.D. (1958) 'Some marshallian concepts, especially the representative firm', Economic Journal, 68: 691-698. 
[30] McKenzie, L (1959) 'On the existence of a general equilibrium for a competitive market', Econometrica, 27: 54-71.

[31] McNulty, P.J. (1967) 'A Note on the History of Perfect Competition', Journal of Political Economy, 75: 395-399.

[32] McNulty, P.J. (1968) 'Economic Theory and the Meaning of Competition', Quarterly Journal of Economics, 82: 639-656.

[33] McNulty, P.J. (1987) 'Competition: Austrian Conceptions', in The New Palgrave: A Dictionary of Economics, J. Eatwell, M. Milgate and P. Newman eds., London: McMillan.

[34] Mill, J.S. (1848) Principles of Political Economy, in Collected Works of J.S. Mill, J.M. Robson ed., Toronto-London: University of Toronto Press, 1965.

[35] Mill, J.S. (1868) Thornton on Labour and its Claims, in Collected Works of J.S. Mill, J.M. Robson ed., Toronto-London: University of Toronto Press, 1967.

[36] Newman, P. (1960) 'The Erosion of Marshall's Theory of Value', Quarterly Journal of Economics, 74: 587-600.

[37] O'Brien, D. P. (1990) 'Marshall's Industrial Analysis', Scottish Journal of Political Economy, 37: 61-84.

[38] Pantaleoni, M. (1898) Pure Economics, New York: Kelly \& Millman, 1957.

[39] Pigou, A.C. (1927) 'The Laws of Diminishing and Increasing Cost', Economic Journal, 37: 188-197.

[40] Pigou, A.C. (1928), 'An Analysis of Supply', Economic Journal, 38: 238257.

[41] Quéré, M. (2003) 'Increasing Returns and Competition: Learning from a Marshallian Perspective', in The Economics of Alfred Marshall, R. Arena and M. Quéré ed., London: Macmillan.

[42] Robertson, D.H. (1930) 'Increasing Returns and The Representative Firm - A Symposium', Economic Journal, 40: 79-116.

[43] Robertson, D.H. (1956), Economic Commentaries, London: Staples Press Limited.

[44] Robinson, J. (1934) 'What is Perfect Competition ?', Quarterly Journal of Economics, 49: 137-140.

[45] Shackle, G.L.S. (1965) A scheme of Economic Theory, Cambridge: Cambridge University Press. 
[46] Shove, G.F. (1942) 'The Place of Alfred Marshall's Principles in the Development of Economic Theory', Economic Journal, 52: 294-329.

[47] Smith, A. (1776) An Enquiry into the Nature and Causes of the Wealth of Nations, R.H. Campbell and A.S. Skinner eds., Indianapolis: Liberty Fund, 1981.

[48] Sraffa, P. (1925) 'Sulle relazioni tra costo e quantità prodotta', in Sraffa, Saggi, Bologna: Il Mulino, 1986.

[49] Sraffa, P. (1926) 'The Laws of returns Under Competitive Conditions', Economic Journal, 52: 535-550.

[50] Sraffa, P. (1930) 'Increasing Returns and The Representative Firm - A Symposium', Economic Journal, 40: 79-110.

[51] Sraffa, P. (1960) Production of Commodities by Means of Commodities: Preface to Critique of Economic Theory, Cambridge: Cambridge University Press.

[52] Stigler, G.J. (1941) Production and Distribution Theories, Ch. IV 'Alfred Marshall', New York: Agathon Press, 1968.

[53] Stigler, G.J. (1957) 'Perfect Competition, Historically Contemplated', Journal of Political Economy, 65: 1-17.

[54] Stigler, G.J. (1987) 'Competition', in The New Palgrave: A Dictionary of Economics, J. Eatwell, M. Milgate and P. Newman eds., London: McMillan.

[55] Thomas, B. (1991) 'Alfed Marshall on Economic Biology', Review of Political Economy, 3: 1-14.

[56] Thornton, W.T. (1869) On Labour: its Wrongful Claims and Rightful Duties, London: Macmillan, 1870.

[57] Triffin, R. (1940) Monopolistic Competition and General Equilibrium Theory, Cambridge, Mass.: Harvard University Press.

[58] Viner, J. (1931) 'Cost Curves and Supply Curves', Zeitschrift fur Nationalokomie, 3: 23-46.

[59] Williams, P.L. (1978) The Emergence of the Theory of the Firm- from Adam Smith to Alfred Marshall, London:Macmillan.

[60] Whitaker, J. K. (1990) 'Marshall's theories of competitive price', in Alfred Marshall in Retrospect, R. McWilliams Tullberg ed., Aldershot: Edward Elgar.

[61] Whitaker, J. K. (2003) 'Alfred Marshall's Principles and Industry and Trade: Two Books or One? Marshall and the Joint Stock', in The Economics of Alfred Marshall, R. Arena and M. Quéré ed., London: Macmillan. 
[62] Wolfe, J. (1954) 'The representative firm', Economic Journal, 64: 337-349. 